\title{
Investigation of Rainbow Trout Farm Effluents on Water Quality of Humestan River (Isfahan, Iran)
}

\author{
Allameh $\mathrm{SK}^{1 *}$, Khayyambashi $\mathrm{B}^{2}$ and Nahavandi $\mathbf{R}^{1}$ \\ ${ }^{1}$ Animal Science Research Department, Isfahan Agriculture and Natural Resources \\ and Education Center, AREEO, Isfahan, Iran \\ ${ }^{2}$ Soil and Water Research Department, Isfahan Agriculture and Natural Resources \\ and Education Center, AREEO, Isfahan, Iran
}

\section{Research Article \\ Volume 1 Issue 3}

Received Date: July 3, 2017

Published Date: July 07, 2017

*Corresponding author: Sayyed Kamaleddin Allameh, Animal Science Research Department, Isfahan Agriculture and Natural Resources and Education Center, AREEO, Isfahan, Iran, Email: Allameh40@gmail.com

\section{Abstract}

In the present study, the impact of effluents exiting from four rainbow trout farms on the water quality of Humestan River (Isfahan, Iran) across 11 stations was investigated. Water samples were collected in the spring, summer, fall and winter and such factors as dissolved oxygen, $\mathrm{pH}, \mathrm{BOD}_{5}, \mathrm{COD}$, ammonia, nitrite, nitrate and phosphorus were measured. The results showed that the amounts of phosphorus entering the River during spring, summer, fall and winter were 311.8 $\mathrm{kg}, 408.1 \mathrm{~kg}, 408 \mathrm{~kg}$ and $683.1 \mathrm{~kg}$, respectively. Furthermore, the amounts of nitrogen entering the River during spring, summer, fall and winter were $1653.75 \mathrm{~kg}, 2164.05 \mathrm{~kg}, 2164 \mathrm{~kg}$ and $3622.5 \mathrm{~kg}$, respectively. The amount of BOD and COD in all sampling stations and in all four seasons was less than 5 and $10 \mathrm{mg} / \mathrm{lit}$, respectively. Due to the very low concentration of ammonia in water samples, no number was reported on the part of laboratories in this case. The amount of nitrite in all four seasons significantly exceeded the recommended level $(0.02 \mathrm{mg} / \mathrm{lit})(P<0.05)$. Given the whole year, it was indicated that the amounts of nitrate and total nitrogen were significantly less than the conventional level $(2$ $\mathrm{mg} / \mathrm{lit})(P<0.05)$. Moreover, the minimum and maximum amounts of phosphate were reported in the spring and winter, respectively, and this amount did not significantly exceed the critical level in any of the seasons $(0.5 \mathrm{mg} / \mathrm{lit})(P>0.05)$. In general, fish farming and effluents imported into Humestan River affected the water quality thereof.

Keywords: Humestan River; Water samples; Nitrate concentration; Water Quality

\section{Introduction}

Given the past 50 years, it is clear that human beings have changed the Earth's ecosystems with an increasing and uncontrollably speed and range compared to similar periods in Earth's history so that they may provide and secure food [1]. At present, rivers and streams in mountainous areas are commonly used in order to produce rainbow trout. However, the expansion of these activities will be followed by large environmental consequences. The construction of fish farming and breeding centers has generated large amounts of effluents and their subsequent importation into the rivers [2]. Interestingly, the effluents caused by rainbow trout farms 


\section{International Journal of Oceanography \& Aquaculture}

can contain such useful substances as pathogens, drugs, disinfectants, feed residuals and fish feces [3]. In fact, production of $1000 \mathrm{~kg}$ of fish leads to generation of 500 $\mathrm{kg}$ of solid waste (including feed residuals and feces). Usually, these effluents and other chemical changes caused by the metabolism of fish are added into river without any purification and, consequently, the quality of water is deteriorated [2]. Generally speaking, since such fish-related activities increase in summer, there are more nutrients in the effluents. Due to the decreased water flow and temperature rise in this season, it is believed that the impact of effluents of fish farms, which are located in the riversides, on the ecosystem and water quality of these rivers will be more severe [3]. Accordingly, several studies have been conducted on the ecological response of natural ecosystems (such as rivers) as well as assessment of threats and risks imposed on these ecosystems. Bayati, et al. reported that effluents flowing from rainbow trout farms into Marbor River could negatively affect the quality of water. Similarly, Naderi-Jelodar, et al. reported that effluents flowing from rainbow trout farms into the river could reduce the number of large benthic invertebrates in the river. In the same vein, Salimi-Bani, et al. and Azimi, et al. [4,5] achieved similar results.

Amankwaah, et al. [6] investigated the impact of effluents flowing from concrete fish ponds into Sophia River in Ghana on the physical and chemical properties of river water. Besides, Pulatsu, et al. [7] examined the impact of effluents flowing from rainbow trout farms into Karasu River in Turkey. Similarly, Bonisławska, et al. investigated the causes of deteriorated water quality of Gunika River in Poland. In addition, Mirrasooli, et al. reported that effluents flowing from rainbow trout farms into Zarrin Gol River negatively affected the quality of water [8,9]. Furthermore, Mazaheri, et al. and Rahimibashar, et al. [10,11] achieved similar results. Given the present study, it was attempted to gauge the impact of effluents of four riverside rainbow trout farms on the water quality of Humestan River (Isfahan, Iran).

\section{Materials and Methods}

\section{Fish Farms and Stations}

There were four rainbow trout farms in the vicinity of Humestan River (Isfahan, Iran). As such, it was attempted to gauge the impact of effluents of four rainbow trout farms on the water quality of Humestan River across 11 stations. The stations were selected on the basis of flowing the river water into the farms and exiting from them, and, then the mixing with effluents at a distance of 50 to 100 meters. Also, two water sampling stations (located at distances of 500 and 1000 meters) were selected in the riverside in which the outlet water of the last farm was mingled with effluents. It should be noted that the latter stations were selected in order to gauge the self-purification of Humestan River. In addition, sampling process was carried out during one year and in different seasons.

\section{Measured Water Quality Parameters}

First, it was attempted to make use of portable devices (EUTECH, Cyberscan 600, Singapor) in order to gauge the level of dissolved oxygen and $\mathrm{pH}$ at each station. Then, one bottle of water was extracted from each station with two repetitions. Then, it was numbered and was sent to the laboratory to measure ammonia, nitrogen, nitrite, nitrate, phosphate, COD and BOD.

\section{Statistical Analysis}

The obtained data were edited in the Excel Software (2010). Next, the data were compared with each other using SAS Software and T-test [12].

\section{Results and Discussion}

\section{Estimation of Entered Phosphorous and Nitrogen to the River}

According to Table 1, the sum of the minimum and maximum food intakes in the concerned four farms were equal to $47250 \mathrm{~kg}$ and $103500 \mathrm{~kg}$ in the spring and winter, respectively. Since fish usually was released in farms during the spring, the minimum consumption of food was observed in this season.

According to the food intakes in four farms (Table 1), it could be said that the amounts of phosphorus entered into the river in the spring, summer, fall and winter were $311.8 \mathrm{~kg}, 408.1 \mathrm{~kg}, 408 \mathrm{~kg}$ and $683.1 \mathrm{~kg}$, respectively. However, the amounts of nitrogen entered into the river in these seasons were $1653.75 \mathrm{~kg}, 2164.05 \mathrm{~kg}, 2164 \mathrm{~kg}$ and $3622.5 \mathrm{~kg}$, respectively. Thus, on average, the daily amounts of $4.96 \mathrm{~kg}$ of phosphorus and $33.71 \mathrm{~kg}$ of nitrogen were entered into the Humestan River as a result of effluents flowing from rainbow trout farms. Pulatsu et al. estimated that up to $12205 \mathrm{~kg}$ of phosphorus (resulting from five rainbow trout farms) entered into the river [7]. Besides, they reported that, on average, the production of $1000 \mathrm{~kg}$ of trout fish led to discharge of $9.38 \mathrm{~kg}$ of phosphorus into the river. Furthermore, they argued that, due to the consumption of $1000 \mathrm{~kg}$ of fish food, a total amount of $8.09 \mathrm{~kg}$ of phosphorus was discharged into the river. Given the present study, it was concluded that the consumption of $1000 \mathrm{~kg}$ of fish food led to discharge of 


\section{International Journal of Oceanography \& Aquaculture}

$6.7 \mathrm{~kg}$ of phosphorus and $35.2 \mathrm{~kg}$ of nitrogen into the Humestan River.

\begin{tabular}{|c|c|c|c|c|}
\hline Farm No. & Spring & Summer & Fall & Winter \\
\hline 1 & 13500 & 31500 & 18000 & 18000 \\
\hline 2 & 15750 & 10350 & 13500 & 40500 \\
\hline 3 & 18000 & 18000 & 27900 & 18000 \\
\hline 4 & No stock & 1980 & 2430 & 27000 \\
\hline
\end{tabular}

Table 1: Mean feed intake $(\mathrm{kg})$ in four rainbow trout farms.

\section{Dissolved Oxygen Changes}

The results showed that although the concentration of dissolved oxygen in the spring was significantly higher than normal $(8 \mathrm{mg} / \mathrm{lit})$, this amount was significantly lower than the concerned level in the other three seasons $(\mathrm{P}<0.05)$. Since the Humestan River (after the last farm) had a wide width, low depth and gravel bedding, it succeeded to absorb the oxygen through the air and provided the necessary concentration for trout fish. Vafai and Abbasi argue that contamination of shallow rivers embedded with a fast water flow and gravel bedding shall be refined faster because these kinds of rivers are characterized with a more oxygen absorption [13]. SalimiBani, et al. and Azimi, et al. [4,5] have examined the status of self-purification and the role of river gauging in promoting water quality in terms of ecological conditions. The investigation of physical and chemical properties of river water in Sophia River in Ghana indicated that the amount of oxygen in the upstream stations were significantly higher than the amount of oxygen in the downstream stations. The same vein, Pulatsu et al. reached similar results in case of Karasu River in Turkey.

\begin{tabular}{|c|c|c|c|c|}
\hline Season & Mean & SD & SE & P value \\
\hline Spring & 9.71 & 0.36 & 0.11 & 0.0001 \\
\hline Summer & 6.91 & 0.35 & 0.1 & 0.0001 \\
\hline Fall & 6.91 & 0.54 & 0.16 & 0.0001 \\
\hline Winter & 7.31 & 0.49 & 0.15 & 0.001 \\
\hline
\end{tabular}

SD: standard Deviation, SE: Standard Error.

Table 2: Comparison of mean dissolved oxygen in each season compared to $8 \mathrm{mg} /$ lit as conventional value.

\section{pH Changes}

In all seasons, $\mathrm{pH}$ changes were not significant across the stations. On average, the lowest and highest levels of $\mathrm{pH}$ were observed in the spring (7.5) and winter (8.58), respectively.
The optimal $\mathrm{pH}$ range for cold water fish has been reported to be 6.5 to 8 (Institute of Standard and Industrial Research of Iran, 2006) [14]. The mean seasons and the upper critical level (i.e., 8) have been statistically compared. Table 4 shows that the $\mathrm{pH}$ level has not exceeded the critical level only in the spring and that it has been located in the desirable range. However, this level is significantly over-critical in the next three seasons $(\mathrm{P}<0.05)$. Thus, fish breeders should take steps to reduce $\mathrm{pH}$ levels in the summer, fall and winter seasons. Amankwaah, et al. [6] investigated the physical and chemical properties of Sophia River in Ghana and concluded that the $\mathrm{pH}$ levels of fish ponds and downstream stations must be located in 7.6-7.9 and 7.487.73 ranges, respectively. Furthermore, they argued that the $\mathrm{pH}$ levels of upstream stations should be located between 7.25 and 7.5. Besides, Pulatsu, et al. [7] investigated the changes in $\mathrm{pH}$ levels in different stations in Karasu River in Turkey and concluded that these changes were not significant at all. Rahimibashar, et al. [11] reported the changes in $\mathrm{pH}$ levels in Shenrood River (Guilan, Iran) during the spring and summer as 7.5 to 8.7, respectively. In the present study, there have been almost similar changes as depicted in aforementioned reports.

\begin{tabular}{|c|c|c|c|c|}
\hline Season & Mean & SD & SE & P value \\
\hline Spring & 7.91 & 0.16 & 0.05 & 0.1223 \\
\hline Summer & 8.16 & 0.2 & 0.06 & 0.0236 \\
\hline Fall & 8.42 & 0.27 & 0.08 & 0.0005 \\
\hline Winter & 8.38 & 0.15 & 0.05 & 0.0001 \\
\hline
\end{tabular}

SD: standard Deviation, SE: Standard Error.

Table 3: Mean pH values in each season compared to 8 as a critical point.

\section{Biological Oxygen Demand (BOD) and Chemical Oxygen Demand (COD)}

The results showed that the levels of BOD and COD were less than 5 and $10 \mathrm{mg} / \mathrm{lit}$ in all sampling stations and in all four seasons. Actually, if $\mathrm{BOD}_{5}$ is greater than 5 and COD is greater than $60 \mathrm{mg} / \mathrm{lit}$, there is a potential for contamination and the risk of lack of oxygen [15]. Therefore, the quality of water at the upstream and downstream stations of the farms has been relatively desirable. This finding is consistent with environmental standards (1993). Rahimibashar, et al. examined the levels of BOD 5 and COD in the Shenrood River (Iran) and reported that these levels were $1.3 \pm 2.2$ and $4.7 \pm 3.4$ $\mathrm{mg} / \mathrm{lit}$, respectively. Similarly, some significant changes were also reported for $\mathrm{BOD}_{5}$ and COD by Pulatsu, et al. in case of Karasu River in Turkey [7]. 


\section{International Journal of Oceanography \& Aquaculture}

\section{Ammonia Changes}

Regarding the very low concentration of ammonia in water samples, it was concluded that there was no significant number in any of the stations. However, it was argued that the low concentration of ammonia in the river water was related to vibrant activities of microorganisms, the speed of water and the gravels resided in the river bed. This possibility was previously acknowledged by Vafai and Abbasi [13]. In this line, Rahimibashar, et al. reported the level of ammonia, caused by effluents of rainbow trout farms in the Shenrood River (Guilan) during the spring and summer as $6.9 \pm 4.8 \mathrm{mg} / \mathrm{lit}$ [11].

\section{Nitrite Changes}

In general, the minimum and maximum amounts of nitrite concentration were observed in the spring and winter, respectively (Table 4). In all seasons, the concentration of nitrite in the outlet of the fish ponds and the place of mixing the effluents with the river was slightly higher than the rest of the stations. Actually, nitrite levels in all four seasons were significantly higher than the recommended level $(0.20 \mathrm{mg} / \mathrm{lit})(P<0.05)$. Therefore, fish breeders are recommended to pay due attention to this factor and think about ways to reduce nitrite levels for downstream farms. Given the results of research conducted by Pulatsu, et al. and Mirrasooli, et al. $[7,9]$, it was indicated that they reported a significant impact of fish breeding activities on the nitrate concentration in the river water. Amankwaah, et al. reported that the average concentrations of nitrite in the upstream and downstream stations of the Sophia River (Ghana) were 7.57 and $5.05 \mathrm{mg} / \mathrm{lit}$, respectively. Furthermore, they reported that the average concentration of nitrate inside the fish ponds was 5 $\mathrm{mg} / \mathrm{lit}$. In this line, Rahimibashar, et al. reported that there was $0.18 \pm 0.9 \mathrm{mg}$ of nitrite per liter in the Shenrood River (Iran). Given the fact that the measured levels were much lower than those aforementioned reports, it was expected that downstream farms might not face a particular problem.

\begin{tabular}{|c|c|c|c|c|}
\hline Season & Mean & SD & SE & P value \\
\hline Spring & 0.03 & 0.01 & 0.0043 & 0.0067 \\
\hline Summer & 0.06 & 0.03 & 0.0109 & 0.0032 \\
\hline Fall & 0.05 & 0.02 & 0.0079 & 0.0008 \\
\hline Winter & 0.25 & 0.25 & 0.0779 & 0.0144 \\
\hline
\end{tabular}

SD: standard Deviation, SE: Standard Error.

Table 4: Mean nitrite values in each season compared to $0.02 \mathrm{mg} /$ lit as a conventional level.

\section{Nitrate Changes}

Table 5 shows that the amount of nitrate in all four seasons was significantly lower than the conventional level $(2 \mathrm{mg} / \mathrm{lit})(\mathrm{P}<0.05)$. Thus, it was expected that downstream farms might not face a particular problem. Besides, the concentration levels of nitrate were higher in winter than other seasons. Similarly, reported the maximum nitrate concentration in the winter [16]. Amankwaah, et al. asserted that the amounts of nitrate in the upstream stations were significantly higher than those in downstream stations and inside fish ponds. Pulatsu, et al. reached similar results in case of Karasu River in Turkey. Also, Mirrasooli, et al. reported a significant impact of fish farms' effluents on the concentration of nitrate in the river water. In this line, Rahimibashar, et al. reported that there was $6.2 \pm 2.7 \mathrm{mg}$ of nitrite per liter in the Shenrood River (Iran).

\begin{tabular}{|c|c|c|c|c|}
\hline Season & Mean & SD & SE & P value \\
\hline Spring & 0.67 & 0.46 & 0.14 & 0.0001 \\
\hline Summer & 1.07 & 0.23 & 0.07 & 0.0001 \\
\hline Fall & 1.03 & 0.24 & 0.07 & 0.0001 \\
\hline Winter & 1.66 & 0.48 & 0.15 & 0.0453 \\
\hline
\end{tabular}

SD: Standard Deviation, SE: Standard Error.

Table 5: Mean nitrate values in each season compared to 2 $\mathrm{mg} / \mathrm{lit}$ as allowance level.

\section{Phosphate Changes}

The minimum and maximum amounts of phosphate were reported in the spring and winter, respectively (Table 6). The amounts of phosphate in the spring and fall were significantly less than $0.5 \mathrm{mg} / \mathrm{lit}$ but these amounts were insignificant in the summer and winter. In fact, the concentration of phosphate did not exceed the critical level in any of the seasons. Pulatsu, et al. and Mirrasooli, et al. confirmed the impact of fish farms' effluents on the amounts of phosphate in the river water. Rahimibashar, et al. reported that there was $0.13 \pm 0.9 \mathrm{mg}$ of phosphate per liter in the Shenrood River (Iran).

\begin{tabular}{|c|c|c|c|c|}
\hline Season & Mean & SD & SE & P value \\
\hline Spring & 0.16 & 0.04 & 0.01 & 0.0001 \\
\hline Summer & 0.42 & 0.16 & 0.05 & 0.1656 \\
\hline Fall & 0.2 & 0.03 & 0.01 & 0.0001 \\
\hline Winter & 0.44 & 0.32 & 0.09 & 0.5822 \\
\hline
\end{tabular}

SD: standard Deviation, SE: Standard Error.

Table 6: Mean phosphate values in each season compared to $0.5 \mathrm{mg} / \mathrm{lit}$ as conventional level. 


\section{International Journal of Oceanography \& Aquaculture}

\section{Conclusion}

In sum, the results showed that since the effluents of rainbow trout farms entered into the Humestan River, the quality of water was negatively affected. This led to an increase in nitrogen and phosphorus in water. Besides, this significantly changed the $\mathrm{pH}$, nitrite and phosphate levels in the river water. However, these changes were not uniform in different seasons. Interestingly, such factors as dissolved oxygen, ammonia, BOD, COD and nitrate did not undergo significant changes.

\section{References}

1. Ferdowsi S (2010) International subjects for sustainability from biodiversity. First Conference on Biodiversity Problems in Central Zagros Zone. PP: 1114.

2. Naderi-Jelodar M, Abdoli A, Morzakhani M, Sharifi R (2011) Macrobenthoses reaction to rainbow trout farm effluents in Haraaz zone. Iranian Journal of Natural Resources 64(2): 163-176.

3. Bayati M, Patimar R, Ebrahimi E, Farhangi M, Forouhar M (2015) Effects of rainbow trout farm effluents on macrobenthoses of Marbor River during low debit (Isfahan Province, Iran). Animal Biology Journal 3: 67-78.

4. Salimi-Bani L, Kaboudvandpour S, Bahrami B, Nikmanesh S (2011) The quality classification of Gavehrood River by Hilsenhoff method using macrobenthoses populations. 5th Special Conferences on Environmental Engineering.

5. Azimi A, Amirnejad R, Nasrollahzadeh H, Soleimani A (2015) Water quality classification of Zarrinehrood River (Mazandaran, Iran) by Hilsenhoff method. Journal of Wetland Ecobiology 23: 39-48.Azimi

6. Amankwaah D, Cobbina SJ, Twaa YA, Bakobie N, Millicent EAB (2014) Assessment of pound effluent effect on water quality of the Asuofia Stream, Ghana. African Journal of Environmental Science and Technology 8(5): 306-311.

7. Pulatsu S, Rad F, Köksal G, Aydın FA, Karasu Benli CK et al. (2004) The Impact of Rainbow Trout Farm
Effluents on Water Quality of Karasu Stream. Turk J Fish Aquat 4(1): 09-15.

8. Bonisławska M, Tański A, Mokrzycka AM, Brysiewicz BA, Nędzarek EA (2013) The effect of effluents from rainbow trout ponds on water quality in the Gowienica River. J Water Land Dev 19(1): 23-30.

9. Mirrasooli E, Nezami S, Ghorbani R, Khara H, Talebi M (2012) The impact of rainbow trout (Oncorhynchus mykiss) farm effluents on water quality. World J Fish \& Marine Sci 4 (4): 330-334.

10. Mazaheri Z, Ghorbani A, Hajimoradloo A, Naeimi A, Fazel A (2013) The effects of trout farm effluents on water quality parameters of Zaringol stream (Golestan, Iran) using NSFWQI and WQI indexes. The International Journal of Environmental Resources Research 1(2): 191-202.

11. Rahimibashar MR, Alipoor V, Issazade K (2012) Environment Effects of Fish Culture Pond on Chemical Factors and Water Quality in the Shenrod River (North of Iran). J Appl Environ Biol Sci 2(8): 358-363.

12. SAS Institute (1998) SAS/STAT User's Guide: Statistics for Windows Company. Release 6.12.0.8. SAS, Institute Inc., Cary, NC.

13. Vafai F, Abbasi A (2012) Study of effective factors on river self-purification mechanism. 2th Conference on planning and management of Environment PP: 1-14.

14. Institute of Standard and Industrial Research of Iran (2006) Water quality parameters for coldwater and warmwater fishes, Standard No. 8726, PP: 21.

15. Esteki AA (2000a) Hydro chemistry. Scientific Report, Registered No. G.A/50, PP: 108.

16. Esteki AA (2000b) Determination of potential production of aquaculture in Hanna Reservoir. Research Report, Iranian Fisheries research Institute PP: 157. 